\title{
The Influence of Low Temperatures on the Mechanical Characteristics of Aluminium Alloys
}

\author{
Ioan GIACOMELLI \\ Transilvania University of Brasov, Romania, giacomelli@unitbv.ro \\ Maria STOICĂNESCU \\ Transilvania University of Brasov, Romania, stoican.m@unitbv.ro
}

\begin{abstract}
Aluminium alloys, widely used in aeronautics, are subject to high temperature fluctuations during short periods of time. The paper studies the behaviour of an alloy of the 7xxx group subjected to repeated cooling and heating. Following the usual heat treatment, the cooling to $70{ }^{\circ} \mathrm{C}$ is applied one to three times in succession. The measurement of some mechanical characteristics, following the application of these procedures, revealed the existence of differences in the values. Therefore, determining the behaviour of these alloys subjected to extreme working conditions is useful.
\end{abstract}

\section{Keywords}

aluminium alloys, mechanical characteristics

\section{Introduction}

7xxx group aluminium alloys are high strength metallic materials due to their chemical composition and to heat treatments. The presence in the $\mathrm{Al}-\mathrm{Zn}-\mathrm{Mg}$-Cu system of the elements that produce hardening through ageing processes enables the achievement of sets of properties making them compatible with the strict requirements of the aerospace industry $[5,6]$.

The structure of these alloys reveals the existence of soluble phases, such as $\operatorname{MgZn}_{2}$ (phase M), $\mathrm{Al}_{2} \mathrm{Mg}_{3} \mathrm{Zn}_{3}$ (phase $\mathrm{T}$ ), $\mathrm{Al}_{2} \mathrm{CuMg}$ (phase $\mathrm{S}$ ), which contribute directly and indirectly to hardening, as well as of some insoluble phases, such as $\mathrm{Al}_{7} \mathrm{Cu}_{2} \mathrm{Fe}$. Figure 1 shows the quaternary diagrams in the $\mathrm{Al}-\mathrm{Zn}-\mathrm{Cu}-$

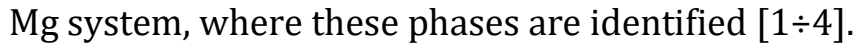

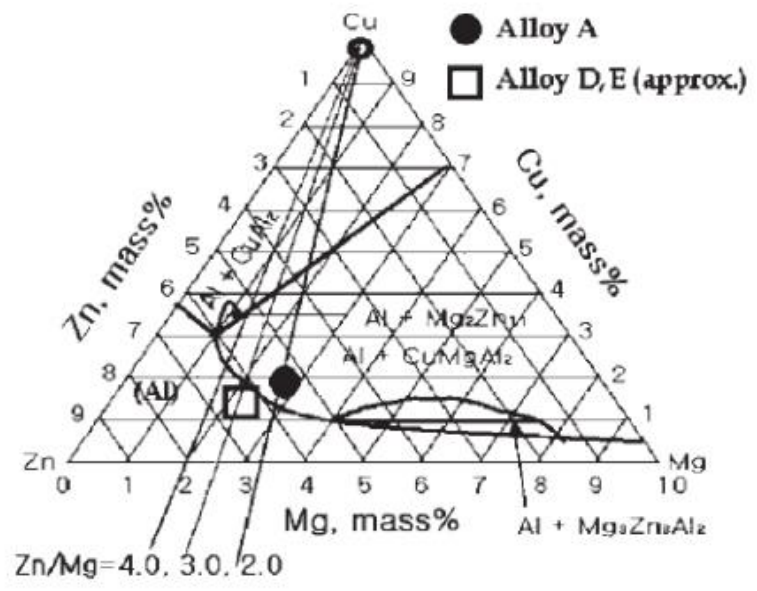

a

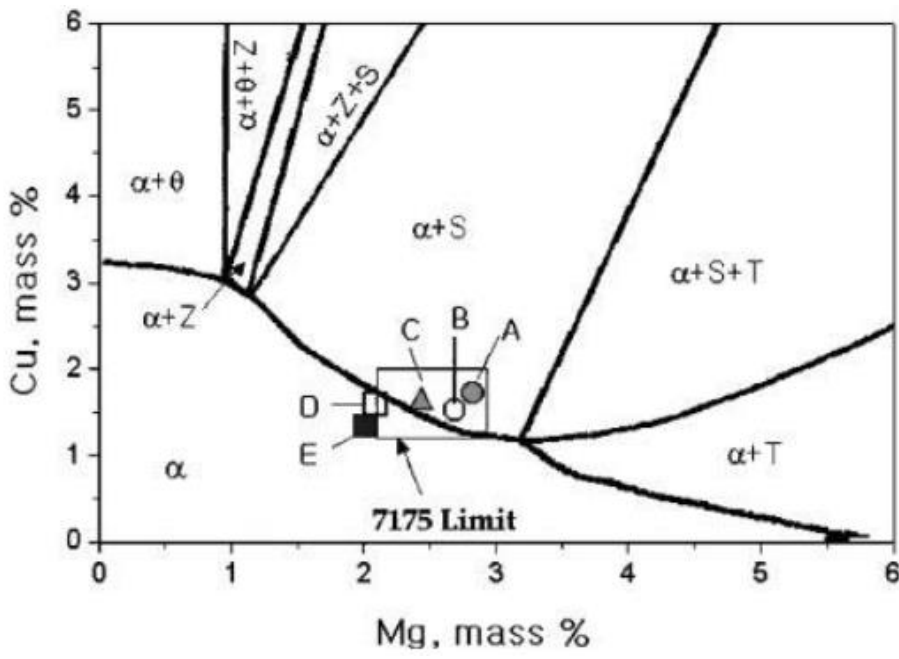

b

Fig. 1. a- The quaternary phase diagram of the $\mathrm{Al}-\mathrm{Zn}-\mathrm{Cu}-\mathrm{Mg}$ system $(90 \%)$ at $733^{\circ} \mathrm{K}\left(460{ }^{\circ} \mathrm{C}\right)$ showing the effect of the $\mathrm{Zn}: \mathrm{Mg}$; b- The quaternary phase diagram of the $\mathrm{Al}-\mathrm{Zn}-\mathrm{Cu}-\mathrm{Mg}$ system at

$$
733^{\circ} \mathrm{K}\left(460^{\circ} \mathrm{C}\right) \text { for } 6 \% \mathrm{Zn}[7]
$$


The $\mathrm{T}$ and $\mathrm{S}$ phases have low melting points and, therefore, they limit the heating intervals for heat treatments and hot works. The S phase content depends on the chemical composition of the alloy and on the temperature.

The experimental research was performed on the alloy whose chemical composition is shown in Table 1.

Table 1 . The chemical composition of alloy 7175

\begin{tabular}{|l|c|c|c|c|c|c|c|c|}
\hline \multirow{2}{*}{ Alloy type } & \multicolumn{7}{|c|}{ Chemical composition [\%] } \\
\cline { 2 - 9 } & $\mathrm{Cu}$ & $\mathrm{Zn}$ & $\mathrm{Mg}$ & $\mathrm{Mn}$ & $\mathrm{Cr}$ & $\mathrm{Fe}$ & $\mathrm{Ti}$ & $\mathrm{Al}$ \\
\hline $\begin{array}{l}7175 \\
(\mathrm{AlZn}\end{array}$ & 1.8 & 5.8 & 2.7 & 0.1 & 0.22 & 0.2 & 0.1 & residue \\
\hline
\end{tabular}

This material was used to make samples for experimental tests and for hardness, resilience and tensile strength measurements. The samples were extracted from the same 7175 alloy plate obtained by hot plastic deformation, cooled in air. The hardness was determined on parallelepiped samples with $l=20 \mathrm{~mm}$.

\section{Experimental Research}

The specimens of the given material were subjected to the final heat treatment in two variants, as shown in Table 2. Please note that the heat treatment parameters were selected taking into account the literature.

Table 2. Applicable heat treatments

\begin{tabular}{|c|c|c|c|c|c|c|c|c|c|}
\hline \multirow{3}{*}{ Material type } & \multirow{3}{*}{$\begin{array}{c}\text { Treatment } \\
\text { variant }\end{array}$} & \multicolumn{3}{|c|}{ Quenching } & \multicolumn{5}{|c|}{ Ageing } \\
\hline & & \multirow[b]{2}{*}{$\begin{array}{c}\text { Temp. } \\
{\left[{ }^{\circ} \mathrm{C}\right]}\end{array}$} & \multirow[b]{2}{*}{$\begin{array}{l}\text { Holding } \\
\text { time [h] }\end{array}$} & \multirow[b]{2}{*}{$\begin{array}{l}\text { Cooling } \\
\text { method }\end{array}$} & \multicolumn{3}{|c|}{ Artificial [1] } & \multicolumn{2}{|c|}{ Natural [2] } \\
\hline & & & & & $\begin{array}{c}\text { Temp. } \\
{\left[{ }^{\circ} \mathrm{C}\right]}\end{array}$ & $\begin{array}{l}\text { Holding } \\
\text { time [h] }\end{array}$ & $\begin{array}{l}\text { Cooling } \\
\text { method }\end{array}$ & $\begin{array}{c}\text { Temp. } \\
{\left[{ }^{\circ} \mathrm{C}\right]}\end{array}$ & $\begin{array}{c}\text { Duration } \\
\text { [days] }\end{array}$ \\
\hline \multirow{2}{*}{$\mathrm{AlZn}_{5.5} \mathrm{MgCu}$} & 1 & 470 & 1 & water & 120 & 2 & air & - & 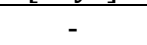 \\
\hline & 2 & 470 & 1 & water & - & - & - & 20/air & 7 \\
\hline
\end{tabular}

The measurements of the specimens treated as above led to the results in Table 3.

Table 3. Mechanical characteristics after the heat treatment

\begin{tabular}{|c|c|c|c|c|}
\hline Material type & Treatment variant & Hardness $[\mathrm{HB}]$ & $\begin{array}{c}\text { Resilience }[\mathrm{KCU}] \\
{\left[\mathrm{J} / \mathrm{cm}^{2}\right]}\end{array}$ & $\begin{array}{c}\text { Tensile strength at } \\
\text { break }\left[\mathrm{N} / \mathrm{m}^{2}\right]\end{array}$ \\
\hline \multirow{2}{*}{$\mathrm{AlZn} 5.5 \mathrm{MgCu}$} & 1 & 97 & 91 & 1450 \\
\cline { 2 - 5 } & 2 & 131 & 70 & 2100 \\
\hline
\end{tabular}

The metallographic structures in different heat treatment states are shown in Figures $2 \div 4$.

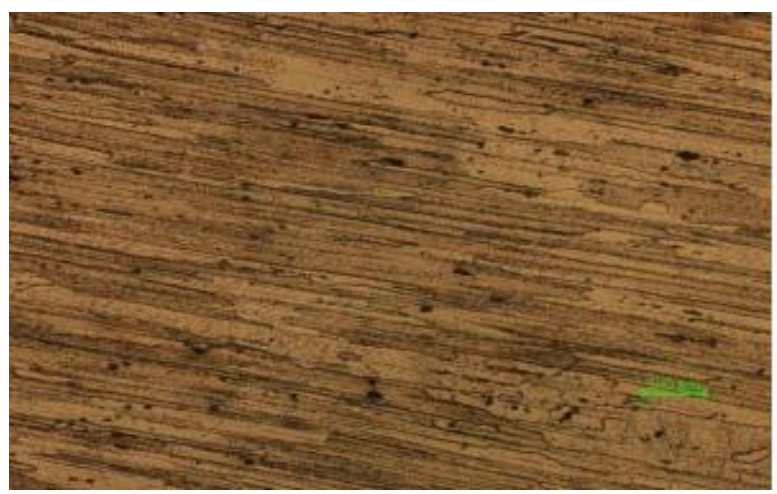

a)

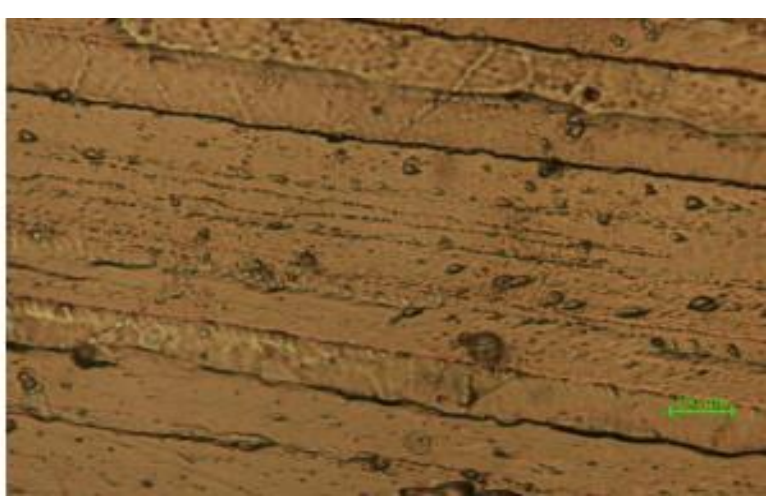

b)

Fig. 2. 7175 alloy in delivery status

a) $100 \times$ magnification; b) $1000 \times$, Nital attack 


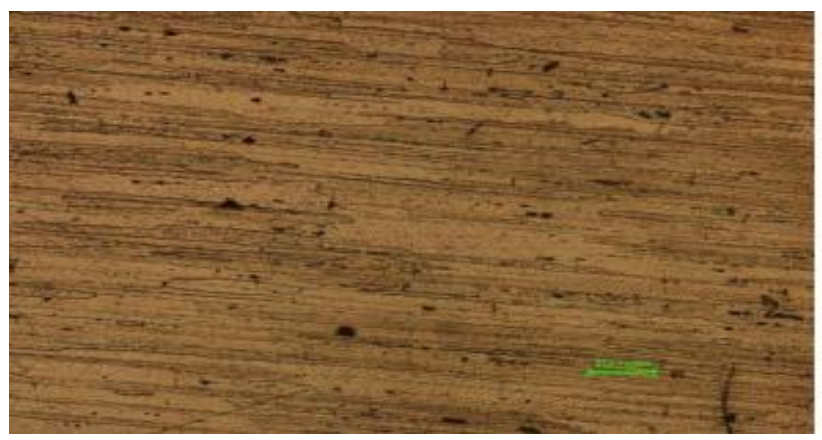

a)

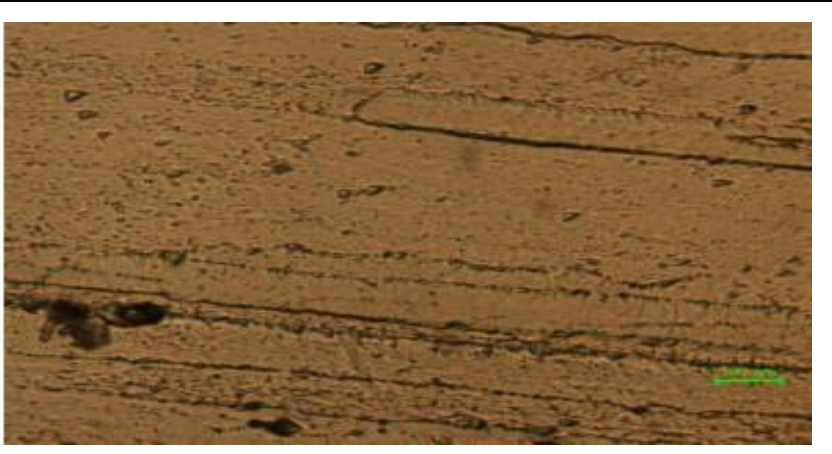

b)

Fig. 3. 7175 alloy hardened at $470{ }^{\circ} \mathrm{C}$ - held $1 \mathrm{~h}$, artificially aged at $120^{\circ} \mathrm{C}$, held $2 \mathrm{~h}$

a) $100 \times$ magnification; b) $1000 \times$, Nital attack

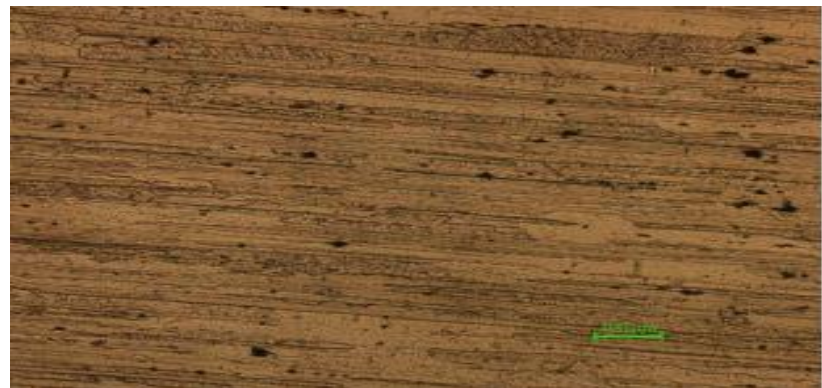

a)

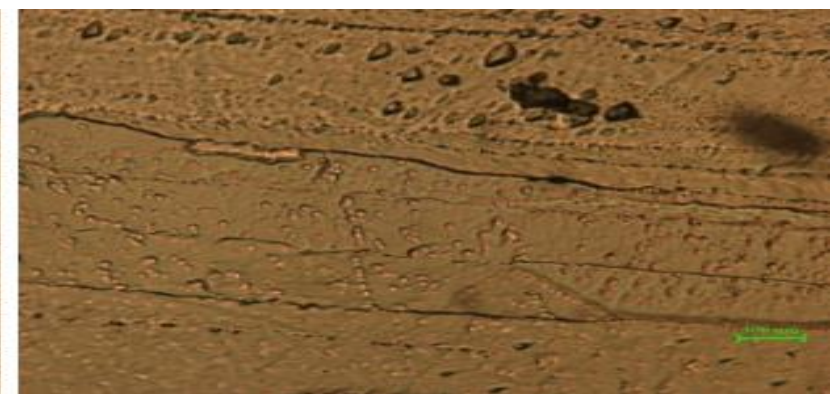

b)

Fig. 4. 7175 alloy after hardening and natural ageing

a) $100 \times$ magnification; b) $1000 \times$, Nital attack

The striped structure, caused by the plastic deformation by lamination, is enhanced in the initial structure. Among the structural constituents, there can be noticed the light coloured base mass of solid solution $\alpha$ and precipitated phases of primary origin, consisting of T, S, M phases.

Following the heat treatment, the changes concern the blurring of the yield lines, as a result of recrystallization and partial homogenization of the structure. The base mass is the same of ss $\alpha$, however it is enriched with the alloying elements of the chemical composition; the total content of precipitated phases decreases accordingly. The ageing processes do not lead to the occurrence of new precipitated phases. The $\theta$ and $\theta^{\mathrm{I}}$ matrix-related phases contribute to the hardening of the alloy and to increasing the breaking strength, respectively. The strength has also increased somewhat as mechanical hardening is more intense than structural hardening.

It is known that most metallic and non-metallic materials become harder at lower temperatures and their elasticity and plasticity decreases significantly.

Seeking the influence of low temperatures on mechanical characteristics, not at cryogenic temperatures, but after returning to ambient temperature, deep cooling was applied. These consisted of cooling to $-70^{\circ} \mathrm{C}$ followed by one hour holding, followed by reheating at room temperature. The samples were kept at room temperature for two hours between two successive cooling processes. One, two or three cooling processes with the same parameters were performed on the samples.

The properties studied were measured after each cryogenic treatment. These are presented in Tables $4 \mathrm{a}$ and $4 \mathrm{~b}$.

Table 4a. Mechanical characteristics after the cryogenic treatment

\begin{tabular}{|c|c|c|c|c|c|}
\hline Material type & Heat treatment & $\begin{array}{c}\text { Number of } \\
\text { processes of } \\
\text { cooling to }-70{ }^{\circ} \mathrm{C}\end{array}$ & $\begin{array}{c}\text { Hardness } \\
{[\mathrm{HB}]}\end{array}$ & $\begin{array}{c}\text { Resilience KCU } \\
{\left[\mathrm{J} / \mathrm{cm}^{2}\right]}\end{array}$ & $\begin{array}{c}\text { Breaking } \\
\text { strength }\left[\mathrm{N} / \mathrm{m}^{2}\right]\end{array}$ \\
\hline \multirow{2}{*}{$\mathrm{AlZn}_{5.5} \mathrm{MgCu}$} & $\begin{array}{c}\text { Quenching and } \\
\text { artificial ageing }\end{array}$ & 1 & 97 & 90.5 & 1390 \\
\cline { 3 - 6 } & 3 & 95 & 85.5 & 1372 \\
\hline
\end{tabular}


RECENT, Vol. 19, no. 1(54), 2018

Table 4b. Mechanical characteristics after the cryogenic treatment

\begin{tabular}{|c|c|c|c|c|c|}
\hline Material type & Heat treatment & $\begin{array}{c}\text { Number of } \\
\text { processes of } \\
\text { cooling to }-70{ }^{\circ} \mathrm{C}\end{array}$ & $\begin{array}{c}\text { Hardness } \\
{[\mathrm{HB}]}\end{array}$ & $\begin{array}{c}\text { Resilience KCU } \\
{\left[\mathrm{J} / \mathrm{cm}^{2}\right]}\end{array}$ & $\begin{array}{c}\text { Breaking } \\
\text { strength }\left[\mathrm{N} / \mathrm{m}^{2}\right]\end{array}$ \\
\hline \multirow{2}{*}{$\mathrm{AlZn} 5.5 \mathrm{MgCu}$} & $\begin{array}{l}\text { Quenching and } \\
\text { natural ageing }\end{array}$ & 1 & 133 & 68.5 & 1980 \\
\cline { 3 - 6 } & 3 & 133 & 65.8 & 1978 \\
\hline
\end{tabular}

The processes of cooling to $-70^{\circ} \mathrm{C}$, irrespective of their number, did not change the metallographic structure, visible at magnifications of up to 1000:1 using the optical microscope.

Since there are no visible changes in the metallographic structure, deep or even multiple cooling processes do not significantly influence the hardness. These have, however, decreased slightly by some Brinell units.

Temperatures of about $-70{ }^{\circ} \mathrm{C}$ lead to the stiffening of the cooled material, to its straining and, possibly, to the formation of micro-fissures in the metallic crystals and the crystal lattice. Upon returning to room temperature, significant decreases in resilience and breaking strength were ascertained. The decrease was higher after the first cooling process, the subsequent decreases were lower. It can be considered that this tendency is maintained during the further cryogenic processes.

\section{Discussions and Conclusions}

The cooling of the material to cryogenic temperatures influences all mechanical characteristics. The effects cumulate the more cooling processes are performed. However, they tend to decrease when the number of cooling processes increases. Higher influences were noticed in terms of hardness. As expected, resilience was most affected. It should be noted that the tensile strength at break was also affected by the number of cooling processes.

It can be concluded that the 7xxx group alloys react to high temperature variations by performance reduction. It can also be noted, however, that a "balance" can be achieved. The decreases found are not likely to lead to the decommissioning of the parts, but they should be taken into account.

\section{References}

1. Liu S., Zhong Q., Zhang Y., Liu W., Zhang X., Deng Y. (2010): Investigation of quench sensitivity of high strength Al-Zn-Mg-Cu alloys by time-temperature-properties diagrams. Materials \& Design, ISSN: 0264-1275, Vol. 31, is. 6, p. 3116-3120, https://doi.org/10.1016/j.matdes.2009.12.038

2. Song R.G., Zhang Q.Z. (2001): Heat treatment optimization for 7175 aluminum alloy by evolutionary algorithm. Materials Science and Engineering: C, ISSN: 0928-4931, Vol. 17, is. 1-2, p. 139-141, D0I: 10.1016/S09284931(01)00322-8

3. Rashed H.M.M.A., Bazlur Rashid A.K.M. (2017): Heat Treatment of Aluminum Alloys. In: Reference Module in Materials Science and Materials Engineering Comprehensive Materials Finishing, Vol. 2, p. 337-371, D0I: 10.1016/B978-0-12-803581-8.09194-3

4. Li C., Han S., Liu S., Deng Y., Zhang X. (2016): Grain structure effect on quench sensitivity of Al-Zn-Mg-Cu-Cr alloy. Transactions of Nonferrous Metals Society of China, ISSN: 1003-6326, Vol. 26, Is. 9, p. 2276-2282, https://doi.org/10.1016/S1003-6326(16)64319-4

5. Stoicănescu M., Giacomelli I. (2006): Aluminiul si aliajele de aluminiu (Aluminum and aluminum alloys), Ed. Transilvania University of Braşov, Romania, ISBN 978-973-635-946-0.

6. Suciu M.V. (1997): Cercetări privind deformarea plastică și tratamentul termic al unor aliaje de aluminiu speciale destinate industriei aeronautice (Research on plastic deformation and thermal treatment of special aluminum alloys for the aeronautical industry). PhD thesis, Technical University of Cluj-Napoca, Romania

7. Lim S.T., Eun I.S., Nam S.W. (2003): Control of Equilibrium Phases (M,T,S) in the Modified Aluminum Alloy 7175 for Thick Forging Applications. Materials Transactions, eISSN: 1347-5320, Vol. 44, No. 1, p. 181-187, https://doi.org/10.2320/matertrans.44.181 